\title{
SAGA GIS FOR INFORMATION EXTRACTION ON PRESENCE AND CONDITIONS OF VEGETATION OF NORTHERN COAST OF ICELAND BASED ON THE LANDSAT TM
}

\author{
Polina LEMENKOVA ${ }^{1 *}$ \\ ${ }^{1}$ Analytical Center, Moscow, 115035, Russian Federation
}

*Correspondence:

Polina LEMENKOVA

pauline.lemenkova@gmail.com

Received: 17 September 2020; Accepted: 20 October 2020; Published: 30 December 2020

\begin{abstract}
The paper aims to evaluate the presence and condition of vegetation by SAGA GIS. The study area covers northern coasts of Iceland including two fjords, the Eyjafjörður and the Skagafjörður, prosperous agricultural regions. The vegetation coverage in Iceland experience the impact of harsh climate, land use, livestock grazing, glacial ablation and volcanism. The data include the Landsat TM image. The methodology is based on computing raster bands for simulating Tassel Cap Transformation (wetness, greenness and brightness) and Enhanced Vegetation Index (EVI) sensitive to high biomass. The results include modelled three bands of brightness, greenness and wetness. Greenness variation shows the least values in ice-covered areas (-56.98 to -18.69). High values (-23.48 to 9.12) are in the valleys with dense vegetation, correlating with the geomorphology of the river network, the vegetation-free areas and ocean which corresponds to the peak of 30.87 to 41.19 . The bell-shaped data distribution shows frequency 43.19-141.74 for vegetation indicating healthy state and canopy density. Maximal values are in ice-covered regions and glaciers $\left(64^{\circ} \mathrm{N}-\right.$ $\left.65^{\circ} \mathrm{N}\right)$. Very low values $(0$ to -20$)$ show desertification and mountainous rocks. Moderate values (20-40) indicate healthy vegetation. The most frequent data: $-28,17$ to 11,8 . The EVI shows data variations (- -0.14 to 0.04). The study contributes both to the regional studies of Arctic Iceland and methodological approach of remote sensing data processing by SAGA GIS.
\end{abstract}

Keywords: Iceland, Landsat TM, SAGA GIS, cartography, vegetation index, machine learning, automatization, mapping.

\section{Introduction}

Geographically, the study area covers the northern coasts of Iceland including its two famous fjords, the Skagafjörður, a deep fjord with a valley $\left(19.4^{\circ} \mathrm{W}-20.0^{\circ} \mathrm{W}\right)$, and the Eyjafjörður, $\left(18.2^{\circ} \mathrm{W}-18.6^{\circ} \mathrm{W}\right)$ one of the longest fjords in Iceland (Fig. 1). The Skagafjörður is one of Iceland's most prosperous agricultural regions, with widespread dairy, sheep farming and horse breeding. Today the vegetation coverage in Iceland has gained more attention in landscape studies due to changes under the impact of various factors including impacts of harsh climate (Brombacher et al., 2020), specifics of land use, intensive livestock grazing, glacial ablation and geological processes. Active volcanism results in regional distribution of the highly erodible volcanic soils. 


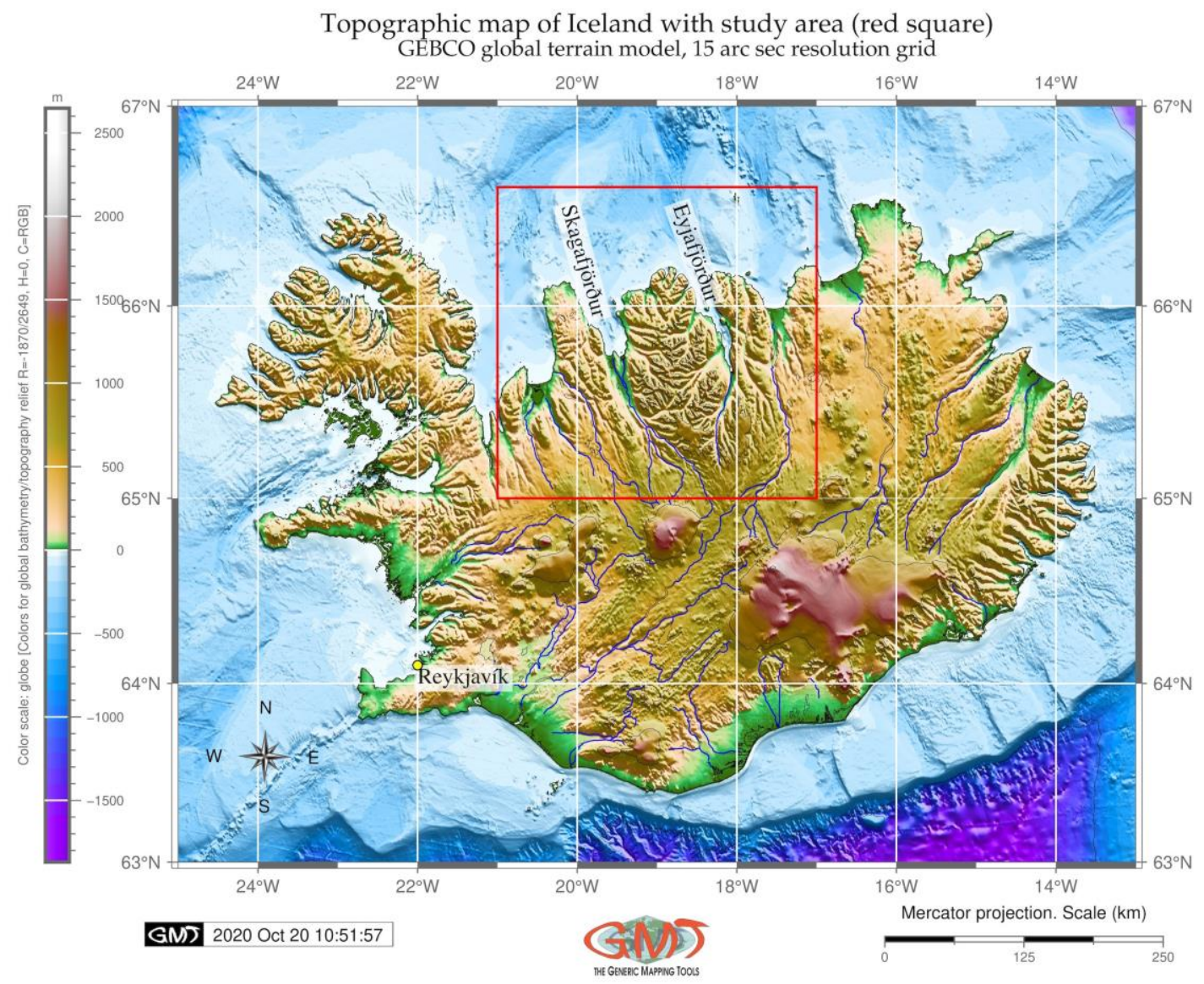

Fig. 1. Topographic map of the study area: Iceland, region of Skagafjörður and Eyjafjörður. Source: author.

According to the recent assessment (Eckert and Engesser, 2013), the country's surface experienced a severe soil erosion on about $40 \%$. As a result, severe land degradation and desertification are considered the most severe environmental problems in Iceland (Eddudottir et al., 2020; Gísladottir, 2001). The examples of land cover changes in Iceland include soil erosion caused by grazing pressure in the processes of sheep farming (Arnalds and Barkarson, 2003), active aeolian processes causing the spread of the sandy areas which replace rich and vegetated ecosystems by lands with low fertility and water-holding capacity (Arnalds et al., 2001). This makes the assessment of the Arctic vegetation coverage by remote sensing methods as an important field at the cutting edge of geoscience.
Current environmental problems in Iceland include severe land degradation which is caused by the effects of both human and climate factors. Land degradation results in the deterioration of plant growth conditions, and the decline of land productivity in sensitive Arctic ecosystems. Land degradation is mirrored in soil deterioration, including its physical, chemical, and biological aspects. Besides, human impacts have been severe on Icelandic soils and vegetation which finally resulted in fragmentary desertification. In turn, vegetation degradation induced soil erosion which successively caused a decline in soil quality. Hence, in recent years soil erosion became an active negative process in Iceland which resulted in deterioration of the grazing areas in the central highlands of Iceland which are not suitable for grazing by sheep due to the 
poor condition. Because the land is a natural complex and comprehensive system of geomorphic landforms, geologic factors (mineral rocks), climate settings, hydrologic conditions, and ecology (vegetation and fauna), land degradation and desertification can have worrying consequences for the fragile Arctic environment.

Analytical studies in the remote sensing of satellite images have unveiled the presence of indicators in plants that may be used to detect the healthiness of the canopy. For instance, chlorophyll as a health indicator of leaves absorbs visible light, and the leaf cell strongly reflects near-infrared light. Parameters of spectral reflectance of leaves are discussed (e.g. Kauth and Thomas, 1976; Broge and Leblanc, 2001; Kim et al., 2010; Lemenkova, 2011; Gao et al., 2020) and widely used for detecting vegetation coverage stage and monitoring their ecological stage. The bands constituting the Landsat TM image scene play an essential role in detecting vegetation health and quality assessed by such indicators as greenness, brightness or wetness. In this context, the use of cartographic methods applied for the satellite image processing, raster bands calculation and visualization have shown promising results in experiments carried out on Landsat TM imagery (Lemenkova, 2015a, 2015b, 2015c; Taufik et al., 2016; Ahmet and Akter, 2017; Zaitunah et al., 2018). The purpose of this study was to use advanced methods of the remote sensing data processing (SAGA GIS) in order to extract information on presence and conditions of vegetation and to receive models of the wetness, greenness and brightness using calculation of the selected raster bands, and to perform calculation of the enhanced vegetation index using embedded formulae in the SAGA GIS, and finally, to visualize data distribution using computed and presented histograms aimed at the environmental monitoring of the selected Arctic ecosystems in Iceland.
Benefits of the presented study include a contribution to the environmental monitoring of the selected regions of Iceland, which includes the two fjords, Skagafjörður and Eyjafjörður which can be used as information on the appropriate level (ecologists, environmentalists, authorities). Because the study is fully based on the open source software (SAGA GIS and occasional GMT) for mapping and data analysis, the benefits for broad public, scolars and students consists in the repeatability of the described methods, algorithms and advices for data capture and resources. Thus, this study presents a broad spectrum of remote sensing data processing and visualization by SAGA GIS, and the use of the standard suite of high-quality raster Landsat TM datasets, as demonstrated and described in this work. Generic Mapping Tools (GMT) was also used for topographic mapping (Fig. 1) aimed at the advanced cartographic visualization of Iceland using available mapping techniques (Lemenkova, 2020a, $2020 b, 2020 c)$. Therefore, this study can be effectively reused for analysis of similar landscapes in Arctic regions using presented workflow of the SAGA GIS and calculation of the Landsat TM raster bands for analysis of vegetation.

\section{Materials and Methods}

This study presents the use of SAGA GIS (Böhner et al., 2006) for processing the Landsat TM image (Fig. 2). The Landsat TM is the satellite imagery of Earth, a joint program of NASA/USGS launched on July 23, 1972 and constrantly being developed since then. Landsat 7 satellite images have eight spectral bands (channels) with spatial resolution ranging from 15 to 60 meters depending on the bands, but mostly 30-meters resolution. The temporal resolution of the Landsat TM is 16 days. Each Landsat scene covers a square approximately $185^{*} 185 \mathrm{~km}$ long and wide. 


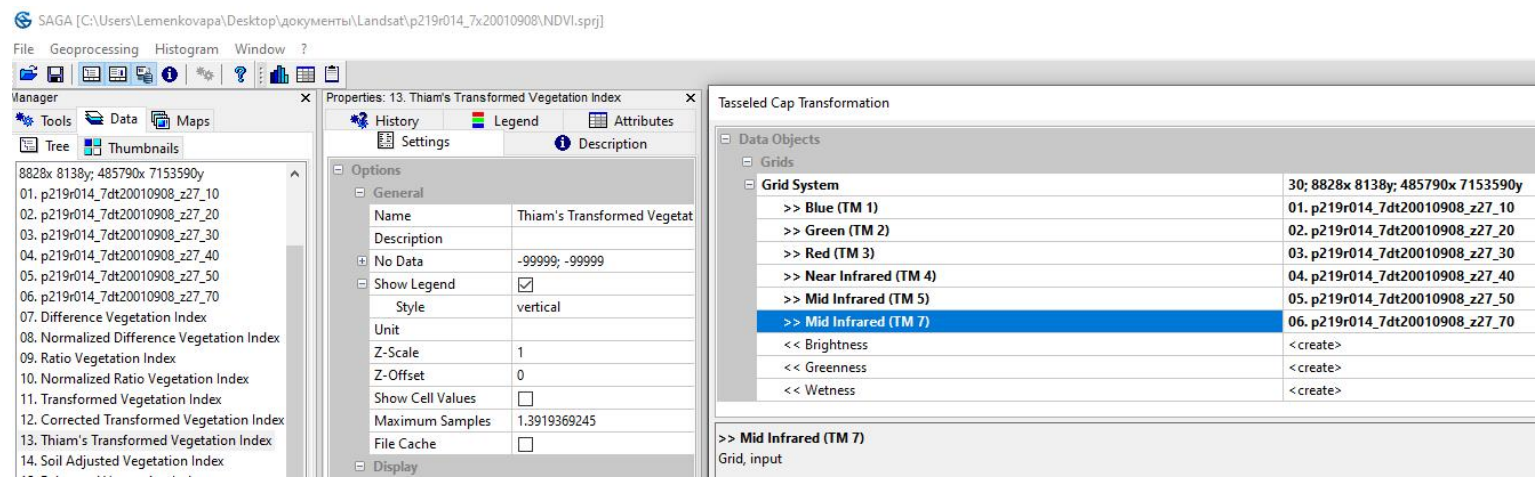

Fig. 2. Applying parameters in SAGA GIS menu. Source: author.

The official website of the Landsat TM is https://landsat.gsfc.nasa.gov/the-thematicmapper/. However, the imagery can be freely downloaded from the GloVis website: https://glovis.usgs.gov/. The methods include two approaches of the image processing: 1) Tasseled cap transformation; 2) Enhanced Vegetation index.

\subsection{Tasseled Cap Transformation}

An algorithm for the Tasseled cap transformation was developed by Kauth and Thomas (1976) to transform the spectral information of the Landsat satellite data into indicators that turned to be useful for analysis of phenological stages of vegetation. In the menu of SAGA GIS it was applied using the following path: 'Geoprocessing $>$ Imagery $>$ Vegetation Indices>Tasseled Cap Transformation'. Using six of seven Landsat TM bands (except for the thermal channel 6) were used for the algorithm.

As a result, three types of information were extracted based on a weighted sum of the Landsat bands: 1) Tasseled Cap Band 1 showing brightness, which is a measurement value for the ground; 2) Tasseled Cap Band 2 showing greenness, which is a measured value for the vegetation; 3) Tasseled Cap Band 3 showing wetness, which is a measured value for interactions of soil and canopy moisture.
In the algorithm, each band (B) was multiplied by a certain coefficient and the three characteristics of the vegetation, brightness, greenness and wetness, were defined as follows (Crist and Cicone, 1984a; 1984b):

1. Brightness $=0.3037(\mathrm{~B} 1)+0.2793(\mathrm{~B} 2)$ $+0.4743(\mathrm{~B} 3)+0.5585(\mathrm{~B} 4)+0.5082(\mathrm{~B} 5)+$ 0.1863 (B7)

2. Greenness $=-0.2848(\mathrm{~B} 1)-0.2435$ $(\mathrm{B} 2)-0.5436(\mathrm{~B} 3)+0.7243(\mathrm{~B} 4)+0.0840$ (B5) -0.1800 (B7)

3. Wetness $=0.1509(\mathrm{~B} 1)+0.1973(\mathrm{~B} 2)+$ $0.3279(\mathrm{~B} 3)+0.3406(\mathrm{~B} 4)-0.7112(\mathrm{~B} 5)-$ $0.4572(\mathrm{~B} 7)$

\subsection{Enhanced Vegetation Index}

For The Enhanced Vegetation Index (EVI) was approached from the SAGA GIS menu using the following path: 'Geoprocessing $>$ Imagery $>$ Vegetation Indices $>$ Enhanced Vegetation Index'. The computing of the EVI was addressed using an optimized numerical method, comparing to the traditional calculations of the vegetation indices, by enhancing the vegetation signal (Jiang et al., 2008).

The formula of the EVI is based on the following equation (Huete et al., 2002):

$$
\mathrm{EVI}=\mathrm{G}^{\times}(\mathrm{NIR}-\mathrm{RED}) /(\mathrm{NIR}+\mathrm{C} 1 \times
$$
$\mathrm{RED}-\mathrm{C} 2 \times \mathrm{BLUE}+\mathrm{L}$ ),

where NIR is a near-infrared band of the electromagnetic spectrum (wavelength at 750 
to $2500 \mathrm{~nm}$ ), RED is a red (wavelength at 625$740 \mathrm{~nm}$ ) BLUE is blue band (wavelength et 450-485 nm). Specifically, the algorithm of EVI has been updated, by focusing on the higher biomass regions using the effects of the improved sensitivity in these specific areas, by de-coupling of the canopy background signal which eventually improved vegetation monitoring, and by a reduction in the atmosphere influences.

\section{Results and discussions}

The simulated Tasseled Cap transformations of Landsat TM data represent examples of linear combination features showing three characteristics of the vegetation: 1) wetness (Fig. 3); 2) greenness (Fig. 4);
3) brightness (Fig. 5). The results of the EVI model are presented in Fig. 6. Analysis of the moisture content in Fig. 3 shows the maximal values concentrated in the ice-covered regions of the glaciers stretching an as long and narrow sheet of ice and two glaciers on the southern part of the region, $64^{\circ} \mathrm{N}-65^{\circ} \mathrm{N}$ (bright red spots in Fig. 3). Very low values of wetness ( 0 to 20) are notable for the areas of local desertification and mountainous rocks (dark grey areas in Fig. 4). Bright yellow colours correspond to moderate values (20-40) which indicates the healthy vegetation. According to the statistics (Fig. 7, upper right), the most frequent data of wetness vary from slightly negative values $-28,17$ to 11,8 .

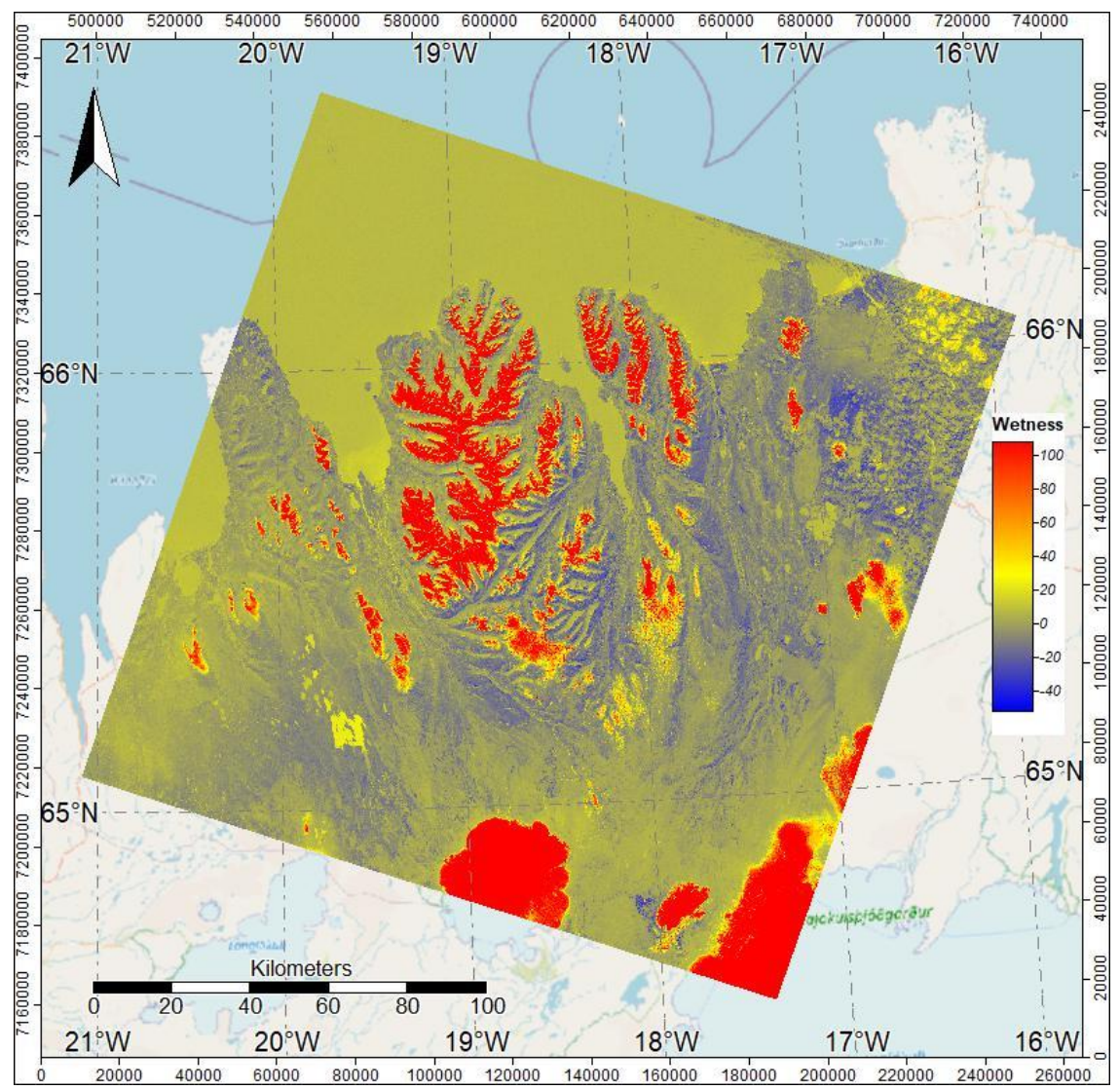

Fig. 3. Wetness of vegetation, modelled by SAGA GIS. Source: author. 


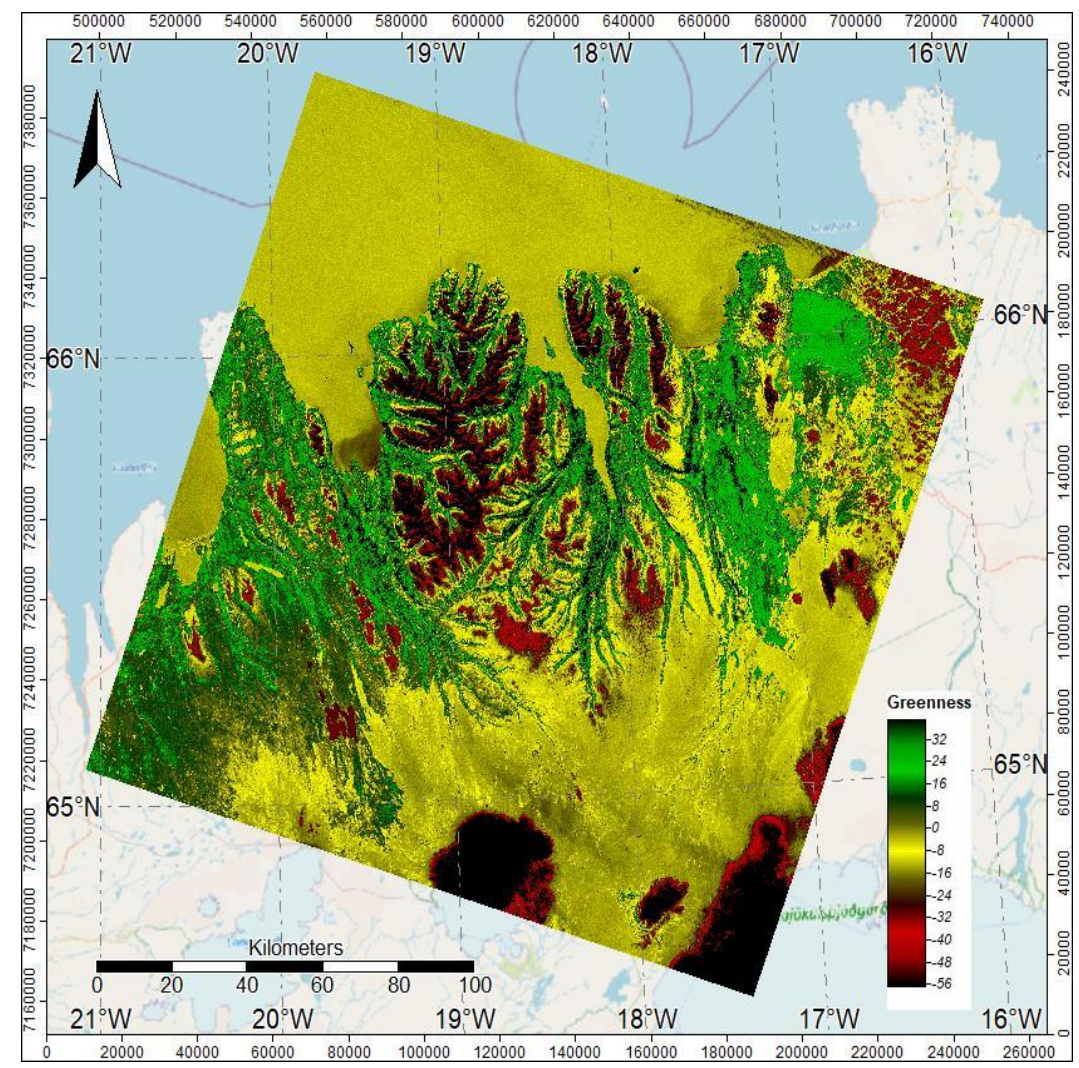

Fig. 4. Greenness of vegetation, modelled by SAGA GIS. Source: author.

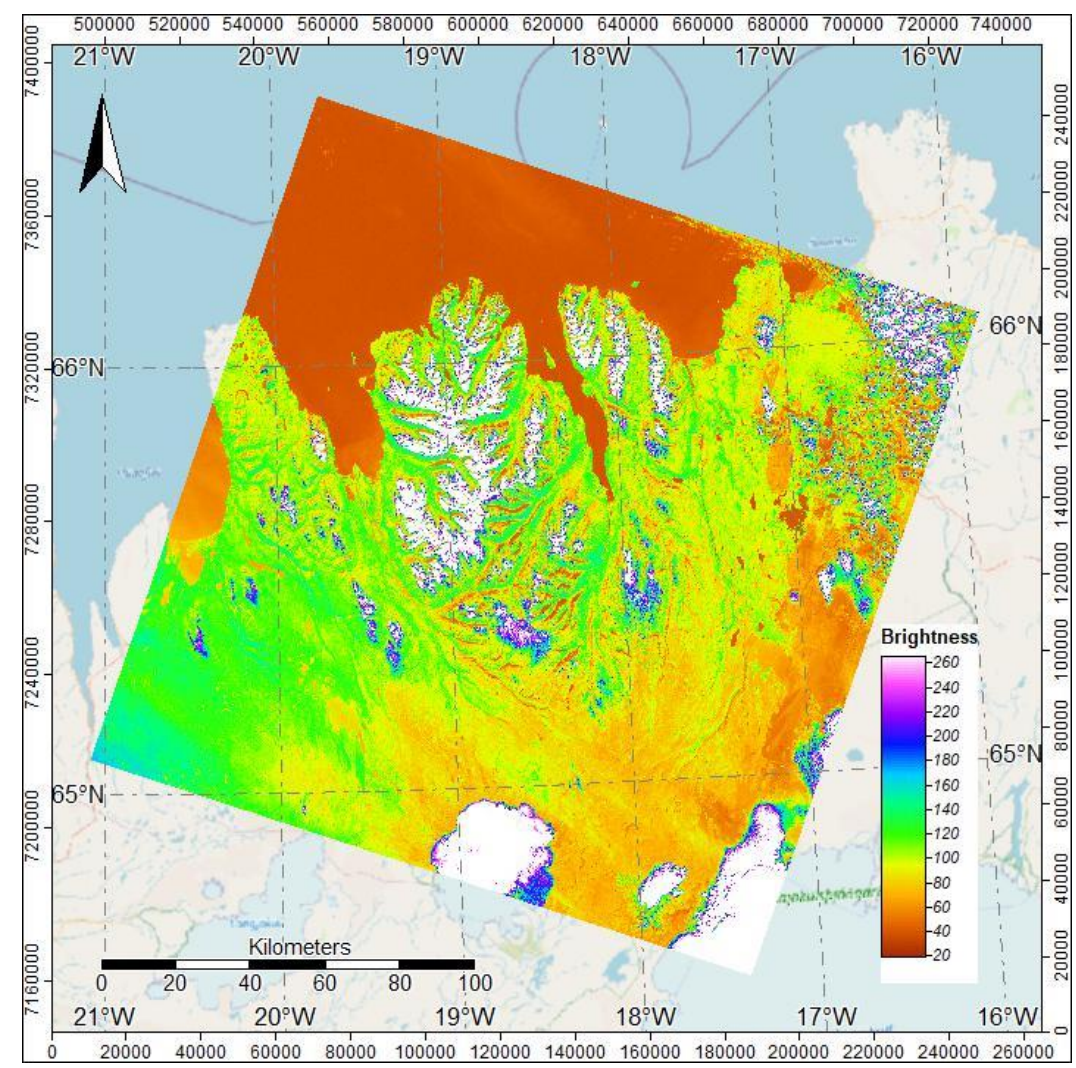

Fig. 5. Brightness of vegetation, modelled by SAGA GIS. Source: author. 


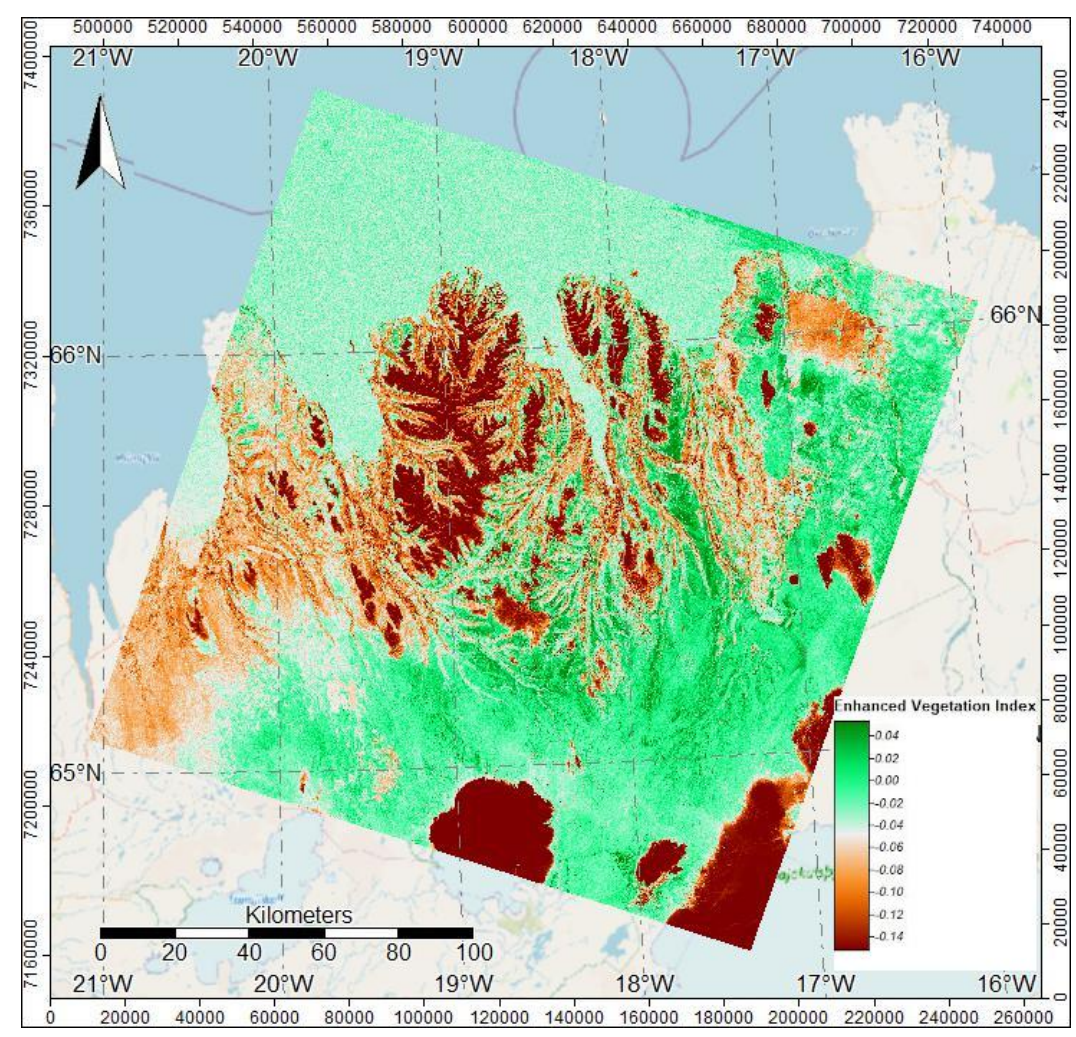

Fig. 6. Enhanced vegetation index, modelled by SAGA GIS. Source: author.

The analysis of greenness variations (Fig. 4) clearly shows that the lowest values of greenness correspond to the ice-covered areas (dark crimson brown colours in Fig. 4) which indicates the low values on the statistical histogram (Fig. 7) ranging from -56.98 to 18.69. On the contrary, high values correspond to the peak on the histogram with values between -23.48 to 9.12 (Fig. 7, lower left). High values of greenness are notable for the river valleys with dense vegetation coverage, clearly depicting the geomorphology of the river network. The absence or very low vegetation coverage can be interpreted from the mustard yellow colours with values 0 to -16 . They are typical for the water areas and rocky terrain.

The analysis of brightness (Fig. 5) shows its variations in the range between 20 and 260 units of surface luminosity. In particular, the darkest areas (brown-coloured, Fig. 5) correspond to the vegetation-free areas and ocean, which corresponds to the peak of 30.87 to 41.19 in Fig. 7 (upper left). In contrast, light green colours correlating with vegetationcovered areas (100-150) can be seen as depicting the river valleys (Fig. 5) and on the coastal areas. White regions show dominating ice-covered mountainous areas. The statistical analysis points at the bell-shaped distribution of the data lying in the range of 43.19 to 141.74 for the areas of vegetation with difference indicating its healthy state and density of canopy. The analysis of the EVI (Fig. 6) shows the variations of the data range between -0.14 to 0.04 . Here the lowest values corresponding to the dark brown colours are notable for the ice-covered areas and glaciers, while vegetation in valleys and coastal areas is depicted by beige. The results showed SAGA GIS to be effective for analysis of the vegetation coverage by Landsat TM bands combination. 

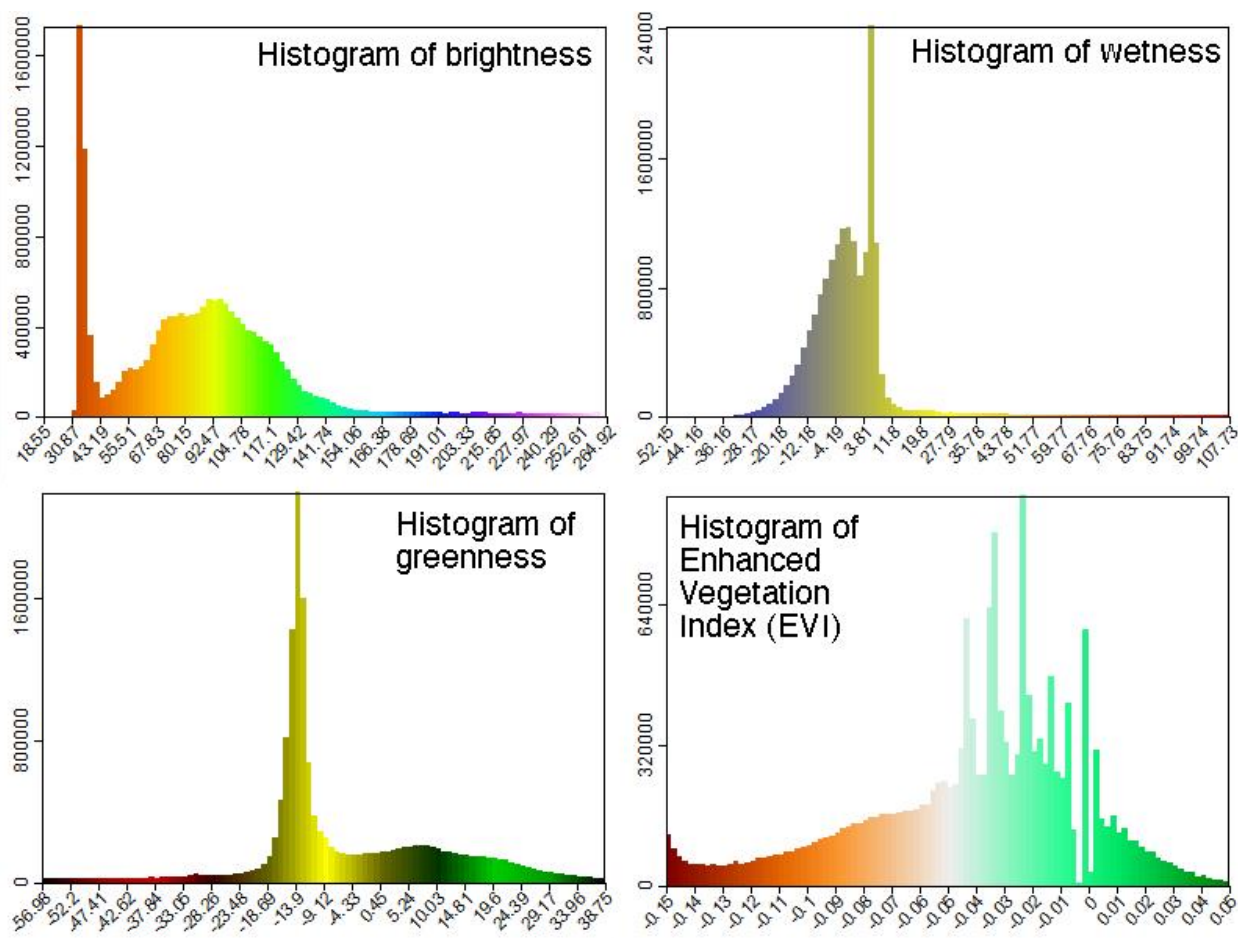

Fig. 7. Four statistical histograms of the data distribution: wetness, brightness, greenness, enhanced vegetation index, modelled by SAGA GIS. Source: author.

Current environmental problems of Iceland include changes in vegetation coverage and anthropogenic pressure, such as increased number of tourists which may cause some mechanical disturbances on fragile Polar landscapes (Ásgeirsdóttir and Karlsson, 2016; Óladóttir, 2019). A complex interaction between various factors affect land cover and vegetation in Iceland, for instance anthropogenic (Tverijonaite et al., 2018), climatic factors (Haraldsson and Ólafsdóttir, 2003). This can be illustrated by issues regarding the vulnerability of the Northern ecosystems, e.g. land use pressure and overgrazing. Since land degradation may affect land use sustainability in the future, these issues present the concern for the environmental monitoring in Iceland. According to previous studies (Bergpórsson et al., 1996), Iceland has experienced climatic variations over the past years which resulted in the changes in vegetation. Besides, due to the anthropogenic effects, over half of the Icelandic vegetation deteriorated from the time of Iceland's first settlement by vikings in ca. AD 830 (Hallsdóttir 1995) and over 90\% of its forest cover (Porsteinsson, 1972). In view of abovesaid, detailed studies of the selected landscapes of Iceland present a contribution to the monitoring of natural resources prevention of degradation of the Northern ecosystems.

\section{Conclusions}

Thanks to the advances in the remote sensing data processing by cartographic methods, the massive amount of Landsat TM images of $30-\mathrm{m}$ resolution and high quality became available in agricultural studies, for instance for a crop or vegetation mapping. Reflectance curves for various land cover types on Earth, including healthy and unhealthy vegetation and its types (coniferous, broadleaf), have particular characteristics (Abburu and Golla, 2015; Knipling, 1970; Lemenkova, 2013). Remote sensing data analysis using spectral reflectance curves shown a trend in 
land cover changes and variations in vegetation coverage of Earth (Lemenkova, 2013, 2015d).

The possibility of synergism between these risk factors remains a topic that can be further researched.

Other studies upscaled the question of the vegetation changes and focused on the quantification of landscape fragmentation by metrics approach for environmental sustainability (Klaučo et al., 2013b, 2014, 2017). Examples of the statistical analysis applied for geosciences provide more advanced methods of data visualization (Lindh, 2004; Klaučo et al. 2013a; Lemenkova, 2019a, 2019b, 2019c). Other ways of geodata processing include machine learning, GIS (Suetova et al., 2005a, 2005b; Schenke and Lemenkova, 2008; Lemenkova, 2014). This review focused on the effective methods of Enhanced Vegetation Index and Tasseled cap transformation by SAGA GIS applied for processing of the Landsat TM scene covering the region of northern Iceland.

The paper contributed both to the agricultural studies of vegetation coverage and the development of methods by presenting twostep methodology: computing raster bands for visualizing the Tassel Cap Transformation and EVI. The application of the Tasseled Cap Transformation and EVI in Arctic vegetation monitoring showed effective methods of data visualization. With a context of the presented case study of Iceland, notable for fragile ecosystems, these two methods demonstrated usefulness for Landsat TM scene analysis of the vegetation canopy, health status and land cover parameters by cartographic means of SAGA GIS.

\section{Conflict of Interest}

The authors declare that the research was conducted in the absence of any commercial or financial relationships that could be construed as a potential conflict of interest.

\section{References}

1. Abburu S, Golla SB (2015) Satellite Image Classification Methods and Techniques: A Review. International Journal of Computer Applications 119(8):20-25.

2. Ahmet KR, Akter S (2017) Analysis of landcover change in southwest Bengal delta due to floods by NDVI, NDWI and Kmeans cluster with Landsat multi-spectral surface reflectance satellite data. Remote Sensing Applications: Society and Environment 8:168-181.

3. Arnalds O, Barkarson BH (2003) Soil erosion and land use policy in Iceland in relation to sheep grazing and government subsidies. Environmental Science \& Policy 6(1):105-113.

4. Arnalds O, Gisladottir F, Sigurjonsson H (2001) Sandy deserts of Iceland: an overview. J. Arid Environment 47:359371.

5. Ásgeirsdóttir T, Karlsson T (2016) International visitors in Iceland - summer 2016. Icelandic Tourist Board. 405 p.

6. Bergpórsson P, Björnsson H, Dýrmundsson Ó, Guðmundsson B, Helgadóttir Á, Jónmundsson JV (1987) The effects on Climatic Variations on Agriculture in Iceland. In: Parry ML, Carter TR, Konijn NT (eds.). The Impact of Climatic Variations on Agriculture, 1. Assessment in Cool Temperate and Cool Regions, 387444, IIASA and UNEP, Dordrecht.

7. Böhner J, McCloy KR, Strobl J (2006) SAGA - Analysis and Modelling Applications. Göttinger Geographische Abhandlungen 115, 130 pp.

8. Broge NH, Leblanc E (2001) Comparing prediction power and stability of broadband and hyperspectral vegetation indices for 
estimation of green leaf area index and canopy chlorophyll density. Remote Sensing of the Environment 76:156-172.

9. Brombacher J, Reiche J, Dijksma R, Teuling AJ (2020) Near-daily discharge estimation in high latitudes from Sentinel-1 and 2: A case study for the Icelandic Pjórsá river. Remote Sensing of Environment 241:111684.

10. Crist EP, Cicone RC (1984a) Application of the Tasseled Cap concept to simulated Thematic Mapper data. Photogrammetric Engineering and Remote Sensing 50(3):343-352.

11. Crist EP, Cicone RC (1984b). A physicallybased transformation of Thematic Mapper data - the TM Tasseled Cap. IEEE Transactions on Geoscience and Remote Sensing GE- 22(3):256-263.

12. Eckert S, Engesser M (2013) Assessing vegetation cover and biomass in restored erosion areas in Iceland using SPOT satellite data. Applied Geography 40:179190.

13. Eddudóttir SD, Erlendsson E, Gísladottir G (2020) Landscape change in the Icelandic highland: A long-term record of the impacts of land use, climate and volcanism. Quaternary Science Reviews 240:106363.

14. Gao L, Wang X, Johnson BA, Tian Q, Wang Y, Verrelst J, Mu X, Gu X (2020) Remote sensing algorithms for estimation of fractional vegetation cover using pure vegetation index values: A review. ISPRS Journal of Photogrammetry and Remote Sensing 159:364-377.

15. Gísladottir G (2001) Ecological Disturbance and Soil Erosion on Grazing Land in Southwest Iceland, Land Degradation. Springer, 109-126.

16. Hallsdóttir M (1995) On the pre-settlement history of Icelandic vegetation. Icelandic Agricultural Science 9:17-29.
17. Haraldsson HV, Ólafsdóttir R (2003) Simulating vegetation cover dynamics with regards to long-term climatic variations in sub-arctic landscapes. Global and Planetary Change 38(3-4):313-325.

18. Huete A, Didan K, Miura T, Rodriguez EP, Gao X, Ferreira LG (2002) Overview of the radiometric and biophysical performance of the MODIS vegetation indices. Remote Sensing of Environment 83:195-213.

19. Jiang $Z$, Huete AR, Didan $K$, Miura $T$ (2008) Development of a two-band Enhanced Vegetation Index without a blue band, Remote Sensing of Environment, 112(10):3833-3845.

20. Kim Y, Huete AR, Miura T, Jiang Z (2010) Spectral compatibility of vegetation indices across sensors: band decomposition analysis with Hyperion data. Journal of Applied Remote Sensing, 4(1):043520.

21. Kauth RJ, Thomas GS (1976) The Tasseled Cap - a graphic description of the spectraltemporal development of agricultural crops as seen by Landsat. Proceedings of the Symposium on Machine Processing of Remotely Sensed Data, Purdue University, West Lafayette, Indiana, 4B41-4B51.

22. Klaučo M, Gregorová B, Stankov U, Marković V, Lemenkova P (2013a) Determination of ecological significance based on geostatistical assessment: a case study from the Slovak Natura 2000 protected area. Central European Journal of Geosciences, 5(1):28-42.

23. Klaučo M, Gregorová B, Stankov U, Marković V, Lemenkova P (2013b) Interpretation of Landscape Values, Typology and Quality Using Methods of Spatial Metrics for Ecological Planning. $54^{\text {th }} \quad$ International Conference Environmental \& Climate Technologies. Riga, Latvia.

24. Klaučo M, Gregorová B, Stankov U, Marković V, Lemenkova P (2014) 
Landscape metrics as indicator for ecological significance: assessment of Sitno Natura 2000 sites, Slovakia. Ecology and Environmental Protection. Proceedings of the International Conference. March 19-20, 2014. Minsk, Belarus, 85-90.

25. Klaučo M, Gregorová B, Stankov U, Marković V, Lemenkova P (2017) Land planning as a support for sustainable development based on tourism: A case study of Slovak Rural Region. Environmental Engineering and Management Journal, 2(16):449-458.

26. Knipling EB (1970) Physical and physiological basis for the reflectance of visible and near-infrared radiation from vegetation. Remote Sensing of Environment 1:155-159.

27. Lemenkova P (2020a) GMT Based Comparative Geomorphological Analysis of the Vityaz and Vanuatu Trenches, Fiji Basin. Geodetski List, 74(1):19-39.

28. Lemenkova P (2020b) Variations in the bathymetry and bottom morphology of the Izu-Bonin Trench modelled by GMT. Bulletin of Geography. Physical Geography Series 18(1): 41-60.

29. Lemenkova P (2020c) GEBCO Gridded Bathymetric Datasets for Mapping Japan Trench Geomorphology by Means of GMT Scripting Toolset. Geodesy and Cartography 46(3):98-112.

30. Lemenkova P (2019a) Statistical Analysis of the Mariana Trench Geomorphology Using R Programming Language. Geodesy and Cartography 45(2):57-84.

31. Lemenkova P (2019b) Testing Linear Regressions by StatsModel Library of Python for Oceanological Data Interpretation. Aquatic Sciences and Engineering 34:51-60.

32. Lemenkova P (2019c) AWK and GNU Octave Programming Languages Integrated with Generic Mapping Tools for
Geomorphological Analysis. GeoScience Engineering 65(4):1-22.

33. Lemenkova P. (2015a) Analysis of Landsat NDVI Time Series for Detecting Degradation of Vegetation. In: Geoecology and Sustainable Use of Mineral Resources. From Science to Practice, Belgorod, Russia, 11-13.

34. Lemenkova P (2015b) Innovations in the Geoscience Research: Classification of the Landsat TM Image Using ILWIS GIS for Geographic Studies. In: Prospects for the Higher School Development. Grodno, Belarus, May 28-29, 2015, 60-63.

35. Lemenkova P (2015c) To the Question of the Environmental Education: how Landsat TM, ETM+ and MSS Images can be Processed by GIS-Techniques for Geospatial Research. Trends and Perspectives in the Creating Regional Systems of the Additional Adults Education. Vitebsk, Belarus.

36. Lemenkova P (2015d) Processing Remote Sensing Data Using Erdas Imagine for Mapping Aegean Sea Region, Turkey. Informatics. Problems, Methodology, Technologies, 3, 11-15.

37. Lemenkova P (2014) Opportunities for Classes of Geography in the High School: the Use of 'CORINE' Project Data, Satellite Images and IDRISI GIS for Geovisualization. In: Perspectives for the Development of Higher Education. Belarus, Grodno, 284-286.

38. Lemenkova P (2013) Monitoring Changes in Agricultural Landscapes of Central Europe, Hungary: Application of ILWIS GIS for Image Processing. Geoinformatics: Theoretical and Applied Aspects. Ukraine, Kiev, 13-16 May, 2013.

39. Lemenkova P (2011) Seagrass Mapping and Monitoring Along the Coasts of Crete, Greece. M.Sc. Thesis. Netherlands: University of Twente. $158 \mathrm{pp}$. 
40. Lindh P (2004) Compaction- and strength properties of stabilised and unstabilised fine-grained tills. $\mathrm{PhD}$ Thesis, Lund University, Lund.

41. Óladóttir OT (2019). Tourism in Iceland in Figures. Icelandic Tourist Board, $28 \mathrm{p}$.

42. Porsteinsson, I. 1972. Gróðurvernd: byggð á hóflegri nýtingu og ræktun lands [Carrying capacity of Icelandic rangelands]. Rit landverndar, 2. Landvernd, Reykjavik, $128 \mathrm{pp}$.

43. Schenke HW, Lemenkova P (2008) Zur Frage der Meeresboden-Kartographie: Die Nutzung von AutoTrace Digitizer für die Vektorisierung der Bathymetrischen Daten in der Petschora-See. Hydrographische Nachrichten 81:16-21.

44. Suetova IA, Ushakova LA, Lemenkova P (2005a) Geoinformation mapping of the Barents and Pechora Seas. Geography and Natural Resources 4:138-142.

45. Suetova IA, Ushakova LA, Lemenkova P (2005b) Geoecological Mapping of the Barents Sea Using GIS. International Cartographic Conference.

46. Taufik A, Ahmad SSS, Ahmad A (2016) Classification of Landsat 8 satellite data using NDVI thresholds. Journal of Telecomunication Electronic and Computer Engineering 8(4):37-40.

47. Tverijonaite E, Ólafsdóttir R, Thorsteinsson $\mathrm{T}$ (2018). Accessibility of protected areas and visitor behaviour: A case study from Iceland. Journal of Outdoor Recreation and Toursim, 24:1-10.

48. Zaitunah A, Ahmad AG, Safitri RA (2018) Normalized difference vegetation index (ndvi) analysis for land cover type using landsat 8 oli in besitang watershed, Indonesia. IOP Conf. Series: Earth and Environmental Science 126:012112. 